\title{
Penentu Kecepatan Pengeluaran Air Susu Ibu setelah Sectio Caesarea
}

\author{
Determinant of Breastmilk Excrection Speed Post Sectio Caesarea
}

\section{Desmawati}

Fakultas Ilmu Kesehatan Universitas Pembangunan Nasional Veteran Jakarta

\begin{abstract}
Abstrak
Pengeluaran air susu ibu (ASI) secara dini adalah syarat penting dalam mendukung pemberian ASI eksklusif. Pengeluaran ASI pada ibu post sectio caesarea sedikit lebih lambat dibanding dengan ibu post partum normal. Tujuan penelitian untuk mengetahui pengaruh posisi menyusui, nyeri setelah sectio caesarea, mobilisasi, rooming in, dan rolling massage terhadap kecepatan pengeluaran ASI pada ibu post sectio caesarea. Populasi penelitian dengan metode cross sectional ini adalah ibu-ibu post sectio caesarea yang berjumlah 90 orang. Hasil penelitian menunjukkan ada hubungan posisi menyusui, nyeri setelah sectio caesarea, mobilisasi aktif, rooming in kontinu, dan intervensi rolling massage dengan kecepatan waktu pengeluaran ASI pada ibu post sectio caesarea (nilai $p=0,000 ; \alpha=0,05$ ). Posisi menyusui yang tepat, nyeri ringan, mobilisasi aktif, rooming in kontinu, dan pemberian intervensi rolling massage 12 jam post sectio caesarea merupakan faktor penentu kecepatan pengeluaran ASI pada ibu-ibu post sectio caesarea. Disarankan ibu post sectio caesarea melakukan hal-hal tersebut. Kata Kunci: Ibu post sectio caesarea, pengeluaran ASI secara dini, post partum
\end{abstract}

\footnotetext{
Abstract

Early distribution of breast milk is an important requirement in supporting exclusive breastfeeding. Early distribution of breast milk in post sectio caesarea mothers is slower than normal post partum. This study aimed to determine the influence of breastfeeding position, pain, mobilization, roomingin, and rolling massage on the early breastmilk distribution on mothers post sectio caesaria. This study used cross sectional approach. Population of this study was mother post sectio caesarea. The research sample consisted of 90 people. The results showed there relationship between rooming in, mobilization, pain, positions breastfeeding and rolling massage with speed of time of early breastmilk distribution on mothers post sectio caesarea ( $p$ value $=0.000 ; \alpha=0.05$ ). Breastfeeding with position right, mild pain, active mobilization, continuous rooming-in, and rolling massage inter-
}

vention 12 hours post sectio caesarea are determining factors in the speed of time of early breastmilk distribution on mothers post sectio caesarea. Suggestion researchers to post sectio caesarea mothers to do all that.

Keywords: Early breastmilk distribution, mother post sectio caesarea, post partum

\section{Pendahuluan}

Berdasarkan Survei Demografi dan Kesehatan Indonesia (SDKI) tahun 2007, terdapat $84 \%$ bayi dibawah enam bulan yang mendapatkan air susu ibu (ASI) eksklusif, naik 20\% dari SDKI tahun 2003.1 Pemberian ASI tanpa makanan pendamping dianjurkan selama enam bulan dan dilanjutkan dengan makanan tambahan sampai usia dua tahun. Lama pemberian ASI terbukti meningkatkan ketahanan hidup bayi. ${ }^{2}$ Namun, pemberian ASI eksklusif terkendala pada hari-hari pertama dan kedua setelah melahirkan sebagai akibat ASI yang belum keluar. Sekitar 65\% bayi baru lahir mendapatkan makanan selain ASI selama tiga hari pertama, dan keadaan ini juga sering terjadi pada ibu-ibu yang melahirkan secara sectio caesarea. ${ }^{3}$

Rata-rata persalinan sectio caesarea di Amerika, mencapai 32\%. ${ }^{4}$ Di sembilan negara Asia mencapai 27\% di negara Amerika Latin (35\%), di Inggris pada tahun 1970 adalah 4,5\%. ${ }^{5}$ Namun, saat ini satu dari empat bayi dilahirkan melalui persalinan sectio caesarea. ${ }^{6}$ Hasil studi di beberapa rumah sakit di China dan Taiwan menunjukkan peningkatan angka persalinan sectio caesarea

Alamat Korespondensi: Desmawati, Fakultas Ilmu Kesehatan Universitas Pembangunan Nasional Veteran, Jl. RS Fatmawati Pondok Labu Jakarta Selatan 12450,Hp.08128134018,e-mail: desmawati.campay@gmail.com 
yang mencapai angka 70\%. ${ }^{7}$ Di Indonesia, jumlah persalinan sectio caesarea adalah sekitar $1,3 \%$ pada tahun 1991 meningkat menjadi 4,1\% pada tahun 2003 dan $6,8 \%$ pada tahun $2007 .{ }^{1}$ Prevalensi persalinan caesar di rumah sakit pemerintah Indonesia adalah sekitar 11 $15 \%$ dan di rumah sakit swasta saat ini dapat mencapai $30-40 \%$. Prevalensi yang tinggi tersebut tentu dipengaruhi banyak faktor termasuk indikasi medis yang mengharuskan ibu menjalani persalinan sectio caesarea. Namun, persalinan sectio caesarea sekarang cenderung dilakukan tanpa indikasi medis, tetapi hanya berdasarkan faktor sosial dan pemahaman pasien yang salah atau faktor dari dokter yang melakukan sectio caesarea tersebut. ${ }^{8}$

Berdasarkan hasil survei data dari rekam medis Rumah Sakit Ibu dan Anak Buah Hati di Tangerang Selatan, tahun 2011, jumlah pasien yang melahirkan secara sectio caesarea 3.339 pasien, pada tahun 2010 adalah 3.170 pasien, meningkat 194 pasien. Sedangkan jumlah bayi baru lahir ( $0-3$ hari post sectio caesarea) yang mendapatkan pengganti air susu ibu (PASI) pada tahun 2011 adalah 1.967 bayi dan pada tahun 2010 adalah 1.845 bayi. Jumlah kenaikan penggunaan PASI pada bayi baru lahir dibandingkan dengan tahun sebelumnya 122 bayi $(3,65 \%)$ sebagai akibat ASI yang belum keluar setelah $24-48$ jam setelah persalinan sectio caesarea. Rata-rata jumlah pasien sectio caesarea per bulan di RSIA Buah Hati berdasarkan survei di tahun 2011 adalah 278 pasien.

Saat ini, persalinan sectio caesarea tidak memakai anestesi umum yang membuat ibu tetap sadar, tetapi keadaan luka di perut relatif menghambat proses menyusui. Nyeri setelah sectio caesarea menghambat produksi dan ejeksi ASI, pelaksanaan tindakan rolling massage tidak dapat diberikan secara dini sebagaimana halnya dengan ibu post partum normal karena ibu belum dapat turun dari tempat tidur walaupun dengan bantuan. Selain itu, bayi juga mengantuk dan kurang responsif untuk menyusu, terutama pada ibu yang mendapatkan obat penghilang rasa sakit sebelum di operasi. ${ }^{9}$ Terdapat perbedaan kecepatan pengeluaran ASI antara ibu post partum normal dengan ibu post sectio caesarea. Pengeluaran ASI lebih cepat pada ibu post partum normal dibanding dengan post sectio caesarea sebagai akibat nyeri efek anestesi dan kurangnya ambulasi/mobilisasi dini. ${ }^{10}$

Tujuan penelitian ini adalah menemukan faktor penentu kecepatan pengeluaran ASI secara dini pada ibu post sectio caesarea sehingga ASI dapat diberikan pada bayi segera setelah bayi lahir seperti pada persalinan normal/spontan. Menentukan intervensi yang dapat dilakukan pada ibu post sectio caesaria dalam rangka mempercepat pengeluaran ASI.

\section{Metode}

Desain penelitian yang digunakan adalah cross sectional dengan menggunakan sumber data primer dengan teknik observasi dan wawancara, menggunakan lembar observasi dan kuesioner. Variabel dependen adalah kecepatan pengeluaran ASI pada ibu post sectio caesarea. Sedangkan variabel independen adalah faktorfaktor yang berhubungan dengan pengeluaran ASI, meliputi posisi menyusui, nyeri setelah operasi, mobilisasi, rolling massage, dan rooming in. Populasi dalam penelitian ini adalah ibu-ibu post sectio caesarea. Sampelnya adalah ibu-ibu post SC yang memenuhi kriteria inklusi pasien setelah sectio caesarea dengan spinal anestesi, tidak mempunyai penyakit penyerta, dengan umur dan jumlah paritas tidak risiko tinggi, dapat baca dan tulis, sehat mental dan bersedia berpartisipasi menjadi responden.

\section{Hasil}

Sebagian besar ibu-ibu post sectio caesarea (54\%) menyusui bayinya dengan posisi tidak tepat karena pengaruh nyeri setelah operasi. Ibu-ibu yang mengeluh nyeri ringan setelah operasi sectio caesarea hanya $45,55 \%$ dan nyeri berat $54,44 \%$. Ibu-ibu post sectio caesarea yang rawat gabung secara kontinu adalah $41,11 \%$, sedangkan yang rawat gabung intermiten $58,88 \%$. Para ibu post sectio caesarea yang dapat mobilisasi aktif masih yaitu tergolong rendah $(44,44 \%)$ dan lebih separuhnya hanya mobilisasi pasif $(55,55 \%)$. Ibu-ibu yang dapat dilakukan rolling massage dalam 12 jam pertama post sectio caesarea hanya $44,44 \%$, sisanya $(55,55 \%)$ baru dapat diberikan setelah 12 jam setelah sectio caesarea.

Berdasarkan nilai rata-rata yang secara statistik berbeda bermakna (nilai $\mathrm{p}=0,000(<0,05)$ posisi menyusui, nyeri setelah sectio caesarea, mobilitas, rawat gabung, rolling massage ditemukan berpengaruh terhadap waktu pengeluaran ASI pertama kali pada ibu post sectio cesarea (Tabel 1). Namun, belum dilakukan penilaian pengeluaran ASI pertama kali pada ibu-ibu post sectio caesarea yang menunjukkan lebih dari 1 aktivitas. Ibu post sectio caesarea yang mengalami nyeri ringan, semuanya menyusui dengan posisi tepat (41 orang). Hanya 40 orang yang dapat mobilisasi aktif dan dapat dilakukan rolling massage dalam 12 jam pertama setalah sectio caesarea karena yang satu orang tersebut agak malas. Selain itu, hanya 37 orang yang dapat rooming in kontinu karena ada bayi yang harus dilakukan perawatan intensif seperti di inkubator.

\section{Pembahasan}

Waktu pengeluaran ASI pada ibu post sectio caesarea lebih lambat dibanding dengan ibu post partum normal. Terlambatnya pengeluaran ASI pada ibu post sectio caesarea tersebut disebabkan oleh berbagai faktor. Di 
Tabel 1. Determinan Pengeluaran ASI Pertama Kali pada Ibu-ibu setelah Sectio Caesarea

\begin{tabular}{|c|c|c|c|c|c|c|}
\hline \multirow{2}{*}{ Determinan } & \multirow{2}{*}{ Kategori } & \multirow{2}{*}{$\mathbf{n}$} & \multicolumn{3}{|c|}{ Pengeluaran ASI pasca sectio caesaria } & \multirow{2}{*}{ Nilai p } \\
\hline & & & Mean & SD & SE & \\
\hline \multirow[t]{2}{*}{ Posisi menyusui } & Tepat & 42 & 9,29 & 6,31 & 0,99 & 0,000 \\
\hline & Tidak tepat & 49 & 62,4 & 11,53 & 1,65 & \\
\hline \multirow[t]{2}{*}{ Nyeri post SC } & Ringan & 41 & 8,14 & 1,00 & 0,11 & 0,000 \\
\hline & Berat & 49 & 38,12 & 28,16 & 2,97 & \\
\hline \multirow[t]{2}{*}{ Mobilitas } & Aktif & 40 & 18,68 & 21,62 & 3,42 & 0,000 \\
\hline & Pasif & 50 & 53,68 & 22,62 & 3,20 & \\
\hline \multirow[t]{2}{*}{ Rawat gabung } & Kontinu & 37 & 23 & & 4,16 & 0,000 \\
\hline & Intermiten & 53 & & & 3,52 & \\
\hline \multirow[t]{2}{*}{ Rolling massage } & 12 jam setelah SC & 40 & 18,68 & 21,62 & 3,42 & 0,000 \\
\hline & $>12$ jam setelah SC & 50 & 53,68 & 22,62 & 3,20 & \\
\hline
\end{tabular}

antaranya pada penelitian ini adalah posisi menyusui, nyeri setelah sectio caesarea, mobilisasi, rawat gabung ibu-anak dan intervensi rolling massage.

Posisi menyusui berhubungan dengan waktu pengeluaran ASI pada ibu post partum sectio caesarea. Posisi yang tepat untuk bayi dan kelekatannya pada payudara ibu sangat penting dalam keberhasilan menyusui. Menyusui akan sukses bila posisi menyusui ibu benar. Empat posisi menyusui yang umum digunakan yaitu posisi cradle hold, cross cradle hold, football hold, dan lying down. ${ }^{11}$ Posisi lying down merupakan posisi menyusui terbaik untuk kenyamanan ibu di hari-hari pertama melahirkan, bila ibu telah yakin bayinya mampu latch on dengan tepat. ${ }^{11}$

Nyeri berat pada ibu post sectio caesarea merupakan faktor yang memperlambat keluarnya ASI. Semakin tinggi nyeri yang dialami ibu post partum sectio caesarea, semakin lambat pengeluaran ASI. Apabila bayi disusui, gerakan menghisap yang berirama akan merangsang saraf yang terdapat di dalam glandula pituitiari posterior. Rangsang refleks ini akan mengeluarkan oksitosin dari pitutiari posterior. Hal ini akan menyebabkan sel-sel mioepitel di sekitar alveoli akan berkontraksi dan mendorong air susu masuk ke dalam pembuluh darah. Refleks ini dapat dihambat oleh adanya rasa sakit, misalnya nyeri jahitan luka operasi pada ibu post sectio caesaria. ${ }^{10}$

Dengan demikian, penting untuk menempatkan ibu dalam posisi yang nyaman, santai, dan bebas dari rasa sakit terutama pada jam-jam menyusui. Terapi musik dan hipnoterapi dapat mengurangi nyeri setelah operasi. Hipnoterapi sebagai terapi cognitive behavior therapic system (CBTS) mempunyai peluang 8,5 kali menurunkan ambang nyeri yang dirasakan oleh pasien setelah operasi. ${ }^{12}$ Terapi musik klasik pada ibu-ibu setelah operasi sectio caesarea dapat mengurangi rasa nyeri ibu setelah anestesi hilang dengan counfounding factor adalah obatobat analgetik. ${ }^{13}$ Perlu penjelasan kepada ibu-ibu sebelum operasi sectio caesarea bahwa menyusui tidak perlu dihentikan mulai selama 24 jam sampai 7 hari setelah prosedur pembedahan. Anestesi dan obat analgetik serta pemberian obat anti nyeri pascaoperasi sectio caesarea tidak mempengaruhi ASI. ${ }^{14}$

Mobilisasi dapat mempercepat waktu pengeluaran ASI pada ibu sectio caesarea. Hal ini menunjukkan bahwa pengeluaran ASI lebih cepat pada ibu sectio caesarea yang melakukan mobilisasi aktif dibandingkan dengan ibu yang melakukan mobilisasi pasif. Ambulasi pada hari pertama setelah pembedahan, pada sebagian besar kasus dengan bantuan perawat, pasien dapat bangun dari tempat tidur sebentar-sebentar sekurangkurangnya 2 kali dan akan melancarkan aliran darah serta aliran let down refleks pada ibu menyusui. Ambulasi dapat ditentukan waktunya sedemikian rupa sehingga kombinasi dengan preparat analgesik yang baru saja diberikan akan mengurangi rasa nyeri. Nyeri berkurang akan memfasilitasi pasien untuk melakukan mobilisasi aktif. Mobilisasi aktif mempercepat penyembuhan luka operasi ibu sectio caesarea yang melakukan mobilisasi aktif. ${ }^{15}$ Luka sembuh akan membuat ibu nyaman menyusui dan ASI menjadi lancar. Pada operasi bagian perut untuk meningkatkan rasa nyaman dan mengurangi rasa nyeri, bantu ibu untuk menyokong daerah pembedahan dengan bantal saat mobilisasi sehingga meningkatkan kenyamanan menyusui. 16 Kenyamanan menyusui akan meningkatkan produksi dan ejeksi ASI.

Produksi dan ejeksi ASI lebih cepat pada ibu yang kulit bayinya sejak lahir dilekatkan kepada kulit ibunya. Hal ini digalakkan dengan penerapan praktik inisiasi menyusui dini (IMD). Pada inisiasi menyusui dini terjadi skin to skin contact antara bayi dan ibu. Semakin sering ibu melakukan kontak fisik langsung (skin to skin contact) dengan bayi akan membantu menstimulasi hormon prolaktin dalam memproduksi ASI. Karena itu pada tahun 2005, American Academy of Pediatrics (AAP) mengeluarkan kebijakan agar ibu dapat terus bersama bayinya di ruangan yang sama dan mendorong ibu untuk segera menyusui bayinya kapanpun sang bayi meng- 
inginkannya. Semua kondisi tersebut akan membantu kelancaran produksi dan ejeksi ASI. Keuntungan rawat gabung diantaranya untuk menggalakkan penggunaan ASI sebagai kelanjutan inisiasi menyusui dini. ${ }^{17}$

Intervensi rolling massage dan areola massage berpengaruh positif terhadap pengeluaran ASI secara dini pada ibu post partum normal. Pada penelitian ini, didapatkan bahwa ibu-ibu yang diberikan rolling massage dalam 12 jam setelah sectio caesarea, ASI keluar 18 jam setelah sectio caesarea. Hasil penelitian lain melaporkan bahwa ibu post partum normal yang diberikan tindakan areola dan rolling massage mempunyai peluang 6 kali lebih cepat pengeluaran ASI dibanding dengan ibu yang tidak diberikan intervensi tersebut. Rata-rata ibu yang diberikan tindakan areola dan rolling massage, ASI keluar dalam 12 jam pertama post partum, sedangkan yang tidak diberikan tindakan tersebut ASI keluar setelah 12 jam pertama post partum. ${ }^{18}$ Penelitian lain melaporkan adanya perbedaan kecepatan pengeluaran ASI pada ibu post sectio caesarea dengan ibu post partum normal. ASI ibu post partum normal lebih cepat keluar dibanding dengan ibu. ${ }^{10}$

Rolling massage yaitu pemijatan pada tulang belakang (costae 5 - 6 sampai scapula dengan gerakan memutar) yang dilakukan pada ibu-ibu setelah melahirkan akan membantu kerja hormon oksitosin dalam pengeluaran ASI, mempercepat saraf parasimpatis menyampaikan sinyal ke otak bagian belakang untuk merangsang kerja oksitosin dalam mengalirkan ASI keluar. Pemijatan tersebut merangsang kerja saraf-saraf perifer yang ada di otot-otot sekitar tulang belakang kemudian diterima hipotalamus dan diteruskan pada hipofise posterior sebagai tempat keluarnya oksitosin dan bekerja untuk merangsang let-down reflex. ${ }^{18}$

Hasil penelitian ini sesuai dengan penelitian sebelumnya, keberhasilan IMD lebih cepat pada ibu post partum normal. ${ }^{17}$ Ditemukan perbedaan pengeluaran ASI pada ibu post partum normal dengan ibu post sectio caesarea yang sama-sama di IMD. Pengeluaran ASI lebih cepat pada ibu post partum normal dibandingkan ibu post sectio caesarea. Hal ini diantaranya disebabkan karena ibu post sectio caesarea mengalami nyeri luka setelah operasi yang mengganggu kenyamanan ibu dan pengeluaran endorfin lambat sehingga aliran darah tidak lancar ke otak. Hipotalamus lambat menerima sinyal yang akan ditransfer ke hipofisis posterior yang mengeluarkan oksitosin dalam merangsang refleks aliran ASI. Selain itu, faktor yang memengaruhi pengeluaran ASI yang lambat pada ibu post sectio caesarea adalah anestesi serta masih banyak pandangan pasien yang tidak memperbolehkan atau mengurangi makan dan minum setelah operasi. Sedangkan pada ibu yang melahirkan normal kapanpun ibu tetap dianjurkan minum dan makan, seperti jeda antara setelah bayi lahir dengan pengeluaran plasenta pun ibu tetap diberikan minum. ${ }^{10}$ Rata-rata pengeluaran ASI pertama kali pada ibu-ibu setelah sectio caesarea setelah dilakukan rolling massage, dengan nyeri ringan, mobilisasi aktif, rooming in kontinu dan posisi menyusui tepat adalah 24 jam setelah sectio caesarea (pada hari pertama). Penelitian di komunitas Puerto Rico melaporkan bahwa hanya 36\% ibu post sectio caesarea memungkinkan untuk menyusui bayinya dibandingkan persalinan spontan sehingga perlu untuk meningkatkan pendidikan kesehatan atau promosi menyusui untuk ibu-ibu setelah sectio caesarea. ${ }^{19}$

\section{Kesimpulan}

Posisi menyusui, nyeri setelah sectio caesarea, mobilisasi, rooming in, dan rolling massage berhubungan dengan kecepatan pengeluaran ASI pada ibu post sectio caesarea. Pada nyeri ringan, pengeluaran ASI lebih cepat yaitu delapan jam setelah sectio caesarea dibandingkan nyeri berat $38 \mathrm{jam}$. Mobilisasi aktif mempercepat pengeluaran ASI yaitu 18 jam dibanding mobilisasi pasif yaitu 53 jam. Rooming in kontinu mempercepat pengeluaran ASI yaitu 23 jam dibanding intermiten yaitu 48 jam. Posisi ibu menyusui yang tepat (dalam penelitian ini adalah posisi lying down) mempercepat waktu pengeluaran ASI yaitu 9 jam dibanding dengan posisi yang tidak tepat yaitu 62 jam. Pemberian intervensi rolling massage secara lebih awal yaitu 12 jam setelah sectio caesarea mempercepat pengeluaran ASI yaitu 18 jam dibanding dengan pemberian rolling massage lebih dari 24 jam post sectio caesarea yaitu 53 jam. Faktor-faktor tersebut berkontribusi dalam pengeluaran ASI secara dini pada ibu post sectio caesarea.

\section{Saran}

Disarankan ibu-ibu post sectio caesaria menyusui dengan posisi tepat yaitu posisi lying down, memberikan intervensi rolling massage seawal mungkin jika kondisi ibu memungkinkan dan dimotivasi untuk melakukan mobilisasi aktif sejak dini. Pelayanan kesehatan disarankan membuat kebijakan program rawat gabung ibu-bayi (rooming in) kontinu bagi ibu-ibu setelah sectio caesarea, serta melakukan intervensi untuk mengurangi nyeri post sectio caesarea seperti nafas dalam, terapi musik klasik, hipnoterapi yang didukung oleh standar operasional prosedur. Saran untuk peneliti selanjutnya adalah menilai pengeluaran ASI pertama kali pada ibu-ibu post sectio caesarea yang menunjukkan lebih dari satu aktivitas di atas, seperti dilakukan rooming in kontinyu, tetapi tidak melakukan mobilisasi aktif atau sebaliknya.

\section{Daftar Pustaka}

1. Badan Pusat Statistik. Macro International. Survei demografi dan kesehatan Indonesia 2007. Calverton, Maryland, USA: Badan Pusat Statistik dan Macro International; 2007. 
2. Besral, Nurmiati. Pengaruh durasi pemberian ASI terhadap ketahanan hidup bayi di Indonesia. Jurnal Makara Kesehatan UI. 2008; 12(2): 47 52 [diakses tanggal 3 Agustus 2012]. Availble from: URL: http://journal.ui.ac.id/upload/artikel/01.

3. Utami R. Bayi sehat berkat ASI eksklusif. Jakarta: Gramedia; 2010.

4. MacDorman, Fay M, Eugene D. Cesarean birth in United States: epidemiologi, trends, and outcomes. Clinics and Perinatology Journal. 2008; 35(2): 293-307.

5. Betran AP, Gulmezoglu AM, Robson M, Merialdi M, Souza JP, Wojdyla D. WHO global survey on maternal and perinatal health in Latin America: classifying caesarean sections. Reproductive Health. 2009; 6: 18.

6. Worden J. Too posh too push. 2011 [cited 2012 Jan 3]. Available from: URL:http://www.netdoctor.co.uk/health_advice/facts/pregnancy_too_ posh.

7. Zhang J, Liu Y, Meikle S, Zheng J, Sun W, Li Z. Cesarean delivery on maternal request in Southeast China. Obstetrics Gynecology. 2008; 111: 1077-82.

8. Meiyetriani E, Utomo B, Besral, Santoso BI, Salmah S. Peran dokter ahli kebidanan dan kandungan. Kesmas Jurnal Kesehatan Masyarakat Nasional. 2012; 7(1): 37-43.

9. Afifah DN. Faktor yang berperan dalam kegagalan praktik pemberian ASI eksklusif (Studi kualitatif). Semarang: Universitas Diponegoro; 2007 [diakses tanggal 6 Desember 2011]. Available from: http:// eprints.undip.ac.id/1034/1/ARTIKEL_ASI.pdf.

10. Desmawati. Perbedaan waktu pengeluaran ASI ibu post sectio caesarea dengan post partum normal. Jurnal Bina Widya Universitas Pembangunan Nasional Veteran Jakarta. 2010; 22(1): 11-6.
11. Bobak, Irene M. Buku ajar keperawatan maternitas. 4th ed. Wijayarini. MA, editor. Jakarta: Penerbit EGC; 2005.

12. Desmawati, Christie. Pengaruh terapi hipnotis terhadap penurunan nyeri pada klien post operasi. Jurnal Bina Widya Universitas Pembangunan Nasional Veteran Jakarta. 2009; 20(4): 149-53.

13. Ria K, Desmawati. Terapi musik media penurun nyeri pada pasien post sectio caesarea di Rumah Sakit Marinir [skripsi]. Jakarta: 2009.

14. Dumphy D. The breastfeeding surgical patient. AORN journal. 2008; 87(4): 759-64.

15. Ancheta RS. Efektifitas mobilisasi dini terhadap penyembuhan pasien post seksio sesarea [monograph on the internet]. Medan: Universitas Sumatera Utara; 2005 [cited 2005 Feb 15]. Available from: http://repository.usu.ac.id/bitstream/123456789/27943/4/Chapter\%2 OII.pdf.

16. Wenner L. Care of the breastfeeding mother in medical surgical areas. Medical Surgical Nursing Journal. 2007; 16(2): 101.

17. Arifah IN. Perbedaan waktu keberhasilan inisiasi menyusui dini antara persalinan normal 2009. Semarang: Universitas Diponegoro; 2009 [cited 2010 Des 15]. Available from: URL: http://eprints.undip.ac.id /10501/1/artikel.pdf.

18. Desmawati. Pengaruh areola massage and rolling massage terhadap pengeluaran ASI secara dini pada ibu post partum normal. Jurnal Bina Widya Universitas Pembangunan Nasional Veteran Jakarta. 2010; 21 (1): 24-9.

20. Ortiz AP, Rios NP, Valencia GR. Caesarean delivery as a barrier for breastfeeding initiation. The Puerto Rican Experience. Journal of Human Lactation. 2008; 24(3): 293. 